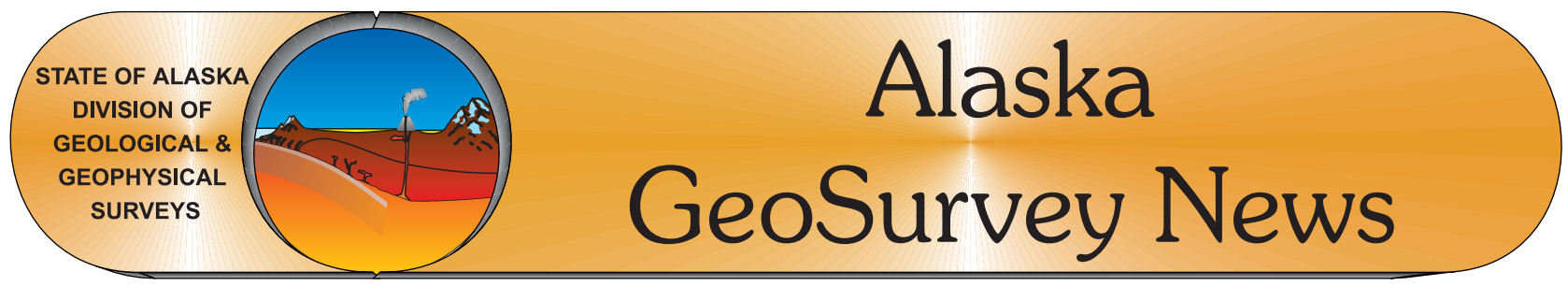

http://www.dggs.dnr.state.ak.us

Vol. 11, No. 2, October 2008

\title{
The Transition from Traditional to Digital Mapping: Maintaining Data Quality while Increasing Geologic Mapping Efficiency in Alaska
}

Jennifer E. Athey ${ }^{1}$, Lawrence K. Freeman ${ }^{1}$, and Kenneth A. Woods ${ }^{1}$

\section{INTRODUCTION}

The Alaska Division of Geological \& Geophysical Surveys (DGGS) Mineral Resources section collects, analyzes, and publishes geological and geophysical information on Alaska's State- and Native-owned lands in order to inventory and manage Alaska's mineral resources. Knowledge of Alaska's mineral resources and framework geology is key to developing and managing a strong mineral industry in the state, which in turn provides employment for Alaska's citizens and revenue to local governments. The Mineral Resources section typically maps and publishes at least one geologic map per year in an area of high mineral potential. In an effort to further streamline the methodology of producing these maps, the DGGS Mineral Resources section is investigating the potential of digital field mapping to create maps more efficiently. Other DGGS sections that conduct fieldwork and publish maps (Energy Resources, Volcanology, and Engineering Geology) may also adopt this technology as situations allow. DGGS anticipates that the move to digital mapping will take a number of years to fully implement and may involve a few false starts. Here, we discuss the issues encountered so far and the choices made to further our objective - increased efficiency via digital mapping.

\section{WHAT IS DIGITAL MAPPING?}

Digital mapping is defined as using a computer or personal digital assistant (PDA) to show and record information that has traditionally been recorded on paper, whether on note cards, in a notebook, or on a map. Geologic mapping is an interpretive process involving multiple types of information, from analytical data to personal observation, all synthesized and recorded by one person. With field experience over time, geologists generally develop efficient, effective personal styles of mapping with which they are comfortable. This "traditional" geologic mapping can be accomplished by a geologist almost as well in inclement weather and when surrounded by mosquitoes as in ideal conditions.

Computer technology and software are now becoming portable and powerful enough to take on some of the burden of the more mundane tasks a geologist must perform in the field, such as precisely locating oneself, displaying multiple maps, plotting structural data, and color coding different physical characteristics of a rock, stratigraphic units, or contact types. Additionally, computers can now perform some tasks that were difficult to accomplish in the field, for example, recording text or voice digitally and annotating photographs on the spot. For digital mapping to become the standard operating procedure, geologists must use the computer in the field to become more efficient, retain their effectiveness as scientists, and create a new but comfortable, personal mapping style.

\section{WHY ARE WE CONSIDERING DIGITAL MAPPING?}

DGGS is constantly looking for ways to improve its geologic mapping workflow. In the end, given the normal, interrelated parameters of funding, available personnel, and time, we want to be as efficient as possible to produce the best possible product. We believe that digital mapping may get us closer to our goal. The main factor driving this effort is the 'time' parameter, in a number of ways.

As of 2006, geologic mapping had been completed for only about 16 percent of Alaska's 586,000-square-mile area at a scale larger than 1:250,000 (fig. 1). Due in part to the scale of available U.S. Geological Survey topographic maps as well as the coverage of existing geologic mapping, most new mapping in the lower 48 states is published at a scale on the order of $1: 24,000$, while new mapping in Alaska is generally published at scales of 1:50,000 or 1:63,360. At the current rate of mapping, DGGS estimates that it will take 250 years to cover the remaining State- and Native-owned bedrock areas of Alaska with 1:63,360-scale geologic maps. That daunting amount of work requires us to focus on areas with time-sensitive, high-impact value to the state, such as mineral and energy potential, hazards to citizens and infrastructure, and transportation corridors.

Not only is there a lot of ground to cover, but a very short season in which to perform fieldwork. The optimal weather window in Alaska lasts three months: June, July, and August.

${ }^{1}$ Alaska Division of Geological \& Geophysical Surveys, 3354 College Rd., Fairbanks Alaska 99709-3707
Email: \{jennifer.athey, lawrence.freeman, ken.woods\}@alaska.gov 


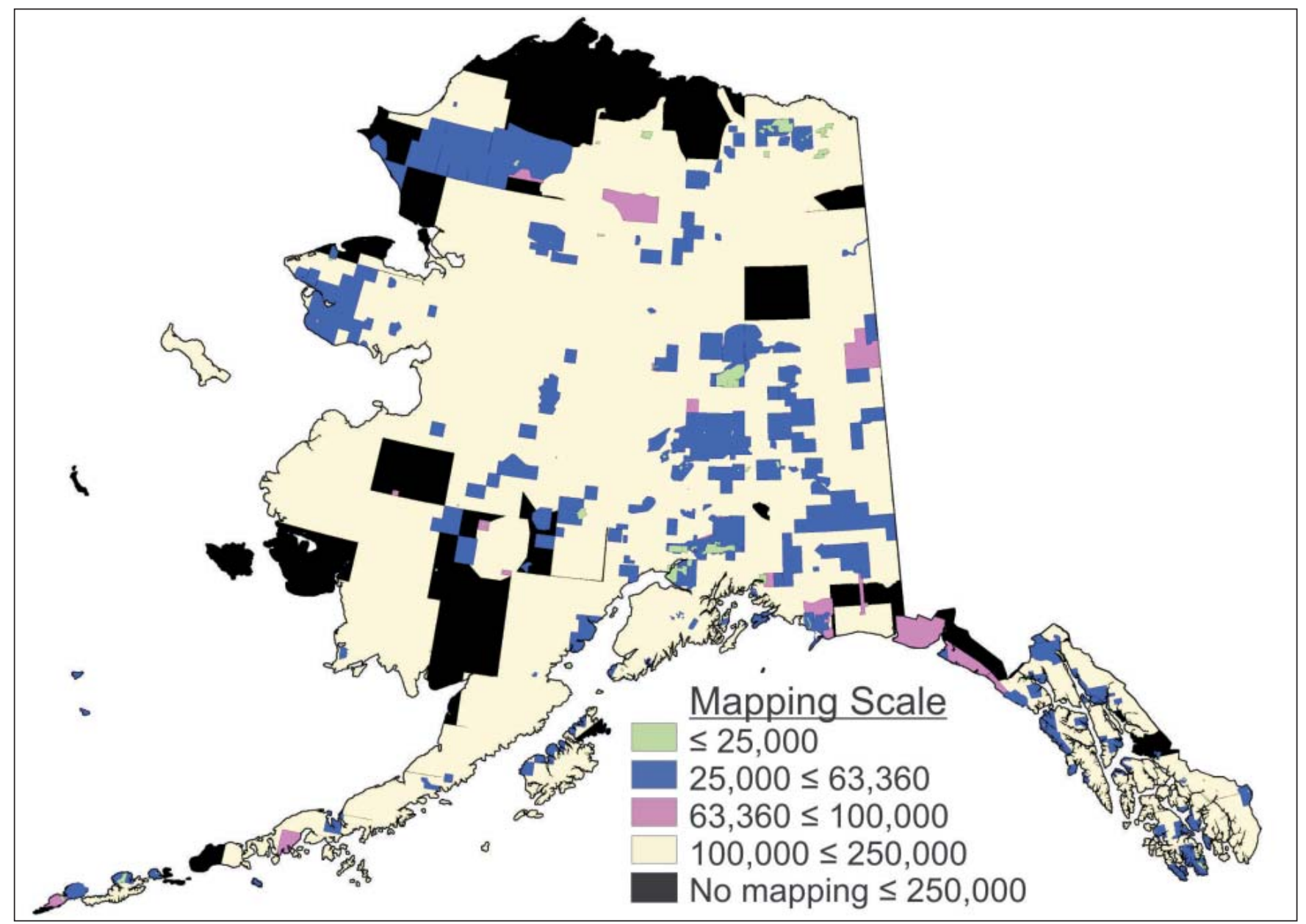

Figure 1. Map of Alaska showing status of bedrock geologic mapping at various scales as of 2006. Note: A significant portion of the Aleutian Islands are not shown on this figure.

Cold temperatures, snow cover, ice overflow in streams, and frozen ground severely hamper geologic fieldwork at other times of the year. The ever-rising cost of fieldwork also plays a large role in the amount of ground covered in a year. Since most of Alaska is inaccessible by road, helicopter transport is a necessary but expensive tool for fieldwork. Other large field expenses include helicopter fuel, fuel transport and storage, remote lodging, food and gear transportation, personnel travel, and rock-sample shipments. To take advantage of the short field season and minimize field costs, DGGS typically deploys a group of five or six geologists that work in the field for up to two months at a time.

Timely release of data to the public and prompt fulfillment of obligations to funding sources are also very important. For example, the Federal STATEMAP program, one of our major funding sources for geologic fieldwork, has a turn-around time of one year for submitting products. With the current mapping methodology, DGGS is challenged to meet this deadline. We believe that the greatest benefit of digital mapping will be a decrease in the amount of project time necessary for data entry, potentially decreasing the overall time needed to complete a project.

\section{EFFECTS ON THE GEOLOGIC MAPPING PROCESS}

DGGS Mineral Resources section first started looking at digital mapping in 2005 as a way to streamline the mapping process. Throughout the mapping process, digital mapping has positive and negative effects; only an assessment of its impact on the project as a whole will show whether it helps or hinders. For simplicity, the mapping process is divided into field operations, data entry and basic data management, and data analysis. The current traditional methodology and the advantages and disadvantages of digital mapping are discussed below for each category. Particularly important advantages or disadvantages are italicized.

\section{EFFECTS ON FIELDWORK}

Currently, DGGS Mineral Resources section employs the team model to conduct fieldwork. A crew of five or six geologists works in the same general area and compares observations nightly. Geologic observations are recorded on rain-proof standardized note cards (fig. 2) and plasticized paper maps. GPS locations are recorded on paper and saved in the GPS. Observations are compiled by each crew member onto a single mylar 


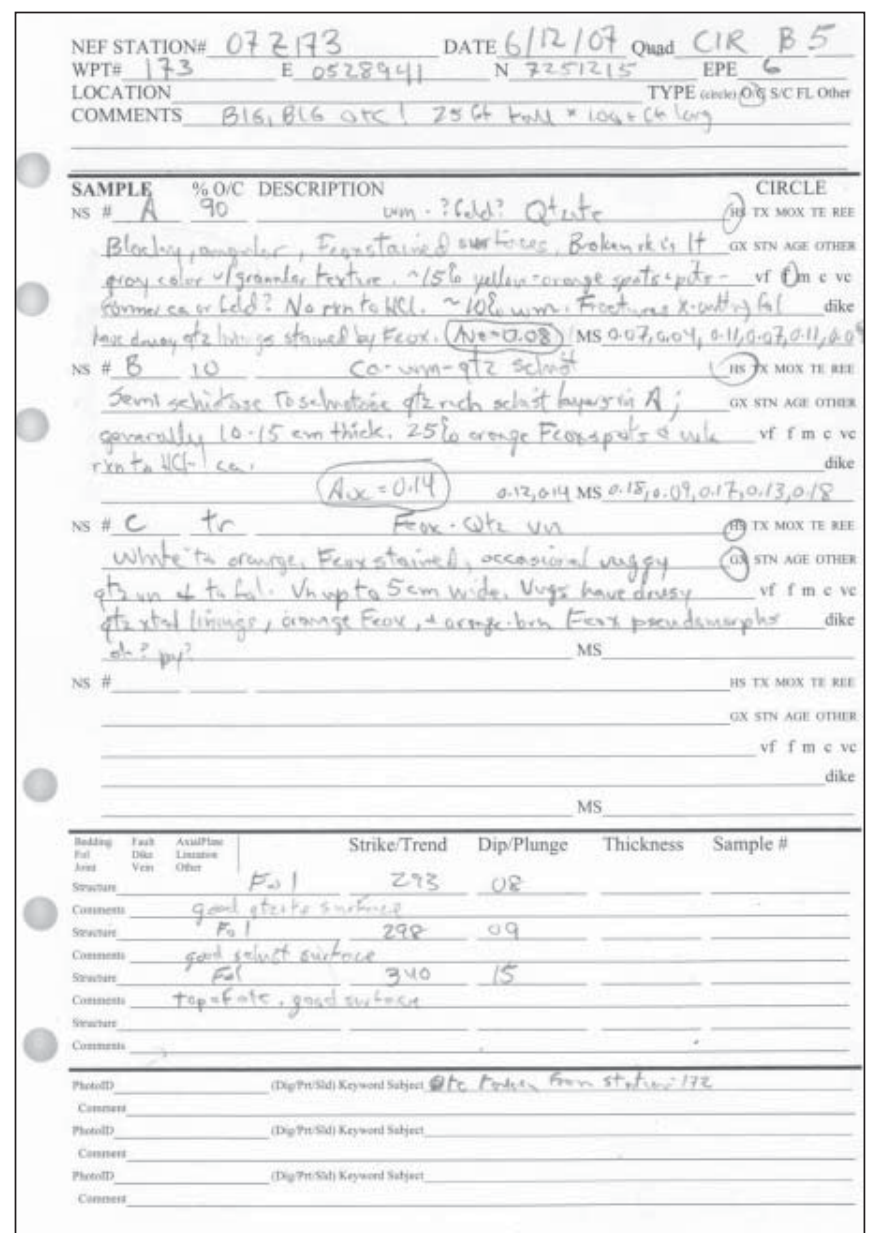

Figure 2. Example of a completed field note card.

basemap in the field office. No one geologist is responsible for the interpretation of an area; instead, geologic interpretations are stronger because the whole crew provides input. Project managers are responsible for arbitrating final interpretations. With the use of digital computers in the field, the recording of observations will change dramatically.

\section{Advantages of Digital Field Mapping: Field Operations}

- Computer screen automatically shows the geographic location of the geologist from the GPS.

- Feature data and attributes are entered directly into GIS. Features can be automatically color coded.

- Station (point) attribute data such as location, rock type, stratigraphic unit, textures, mineralogy, and magnetic susceptibility are recorded directly by the geologist into a database. The geologist has total control of how the data are parsed into the database.

- Structural data are plotted automatically.

- Geologists can pare down lengthy narrative descriptions into multiple data fields, making the data more easily searchable and queryable.

- Feature (point, line, and polygon) attributes are saved as digital text.
- Geologists can upload each others' data files for the next day's fieldwork as reference.

- Multiple maps and imagery (geophysics, orthophotos, etc.) are easily carried and displayed on-screen.

- Geologists can take photographs and annotate them in the field. Photographs are immediately associated with a location.

- Hand-drawn sections, stratigraphic columns, outcrop interpretations, and other drawings are captured digitally. Drawings are immediately associated with a location.

Disadvantages of Digital Field Mapping: Field Operations

- Computers and related items (extra batteries, rain-proof cases, etc.) have to be carried in the field.

- Because computers are more fragile than waterproof paper, geologists have to take more care with them. (In most cases, short of a complete computer submersion in water, data can be recovered from the hard drive.)

- Geologists must undergo extra training to use the hardware, software, and database and be comfortable with their use.

- Data entry into the computer by the geologist takes longer than physically writing on paper, possibly resulting in longer field programs.

- Descriptive narratives often convey to the reader detailed information through imagery that is not communicated by the same data in parsed format.

- Geologists may be inclined to shorten narratives because they are more difficult to enter, resulting in loss of data.

- Details present in some hand-drawn figures like stratigraphic sections, columns, and outcrop interpretations cannot be captured by tablet-stylus entry, resulting in loss of data.

- Geologists may have a more difficult time seeing the regional perspective on a seven-inch computer screen than on larger paper maps, because panning is required.

\section{Effects on Data EnTry and Basic Data Management}

DGGS Mineral Resources section currently hires student interns to perform data entry and basic data management for field projects. In the field office, the intern enters GPS data and field station data from standardized note cards into an Access database (fig. 3). The intern translates poor handwriting and abbreviations, interprets the geologic notes, and parses the data into a complicated set of database forms. It is not uncommon for data to be mistranslated or parsed into incorrect fields within the database, and these errors are difficult to identify.

In the past few years, interns have spent up to seven months during and after the field season performing data entry. This part of our current methodology needs the most improvement, since interpretation by the geologist must wait until data loading is completed. A long period of data entry can delay the whole project. 


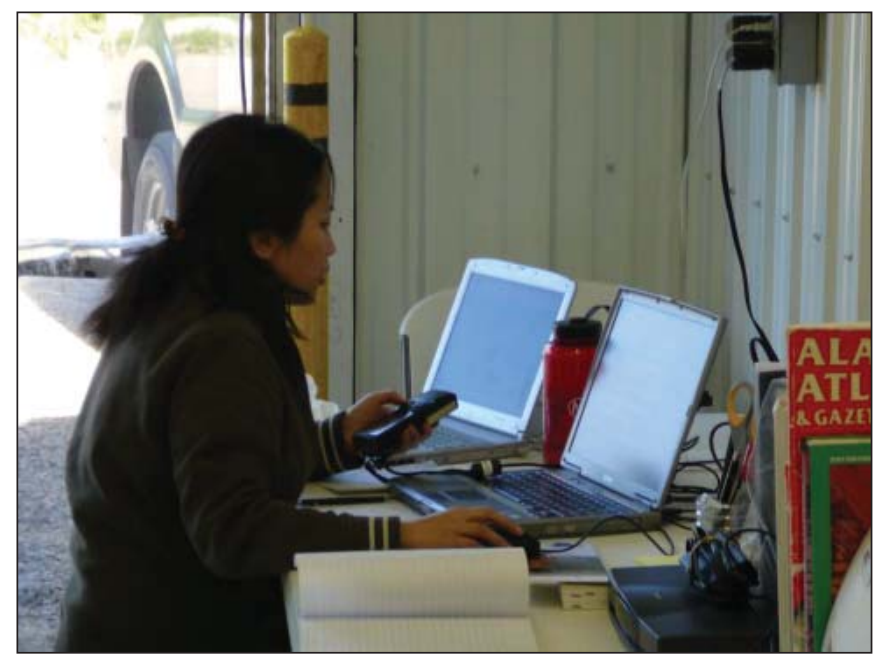

Figure 3. Student intern Liping Jing downloads GPS data into the database.

Advantages of Digital Field Mapping: Data Entry and Management

- Data entry by geologists only (no student intern) takes less total time, potentially reducing the overall time needed to complete a project.

- Data entered by geologists have fewer errors.

- Interns have additional time during the day to work with field geologists.

- Post fieldwork, interns' time is better spent gaining experience and helping with sample preparation, data analysis, and GIS.

Disadvantages of Digital Field Mapping: Data Entry and Management

- Interns need additional training in database replication and synchronization.

- Nightly, databases need to be downloaded, synchronized, and uploaded onto field computers.

- Interns need training in GIS and operation of field computers.

- Nightly, GIS files need to be backed up from field computers, compiled, and re-uploaded.

- There are no original, hardcopy field maps or notes to archive. Paper is arguably a more stable medium than digital format.

\section{Effects on Data Analysis}

Geologic units in Alaska are typically defined at the scale of 1:250,000. The more detailed 1:63,360-scale mapping completed by DGGS tends to break out new lithologies (rock units with specific physical characteristics) and change previous geologic interpretations. Defining new lithologies and creating a bedrock geologic map is an iterative process requiring the spatial analysis of field data, airborne magnetics and resistivity geophysical data, geochemistry, petrography (classification of rocks by microscopic examination), age data, and other information. Mineralogical and textural data and magnetic susceptibility are queried from the database to help differentiate lithologic units (fig. 4). Digital mapping would affect when data analysis could occur, but not greatly affect the process itself.

\section{Advantages of Digital Field Mapping: Data Analysis}

- Analysis of field data can start immediately after returning from the field, since the database has already been populated.

- GIS data input in the field can be directly added to the digital working copy of the map.

\section{Disadvantage of Digital Field Mapping: Data Analysis}

- Data entered by multiple geologists contain more inconsistencies than data entered by one person, making the database more difficult to query.

\section{DIGITAL FIELD MAPPING EQUIPMENT}

In practice, digital geologic mappers are expensive and difficult to outfit. The initial cost of computing and supporting equipment may be significant. In addition, equipment and software must be replaced occasionally due to damage, loss, and obsolescence. Hardware and software only recently (in 2007 and 2008) became available that can satisfy most of the criteria DGGS identified in 2005 as necessary for digital mapping (table 1). Products moving through the market are quickly discontinued as technology and consumer interests evolve. A product that works well for digital mapping may not be avail-

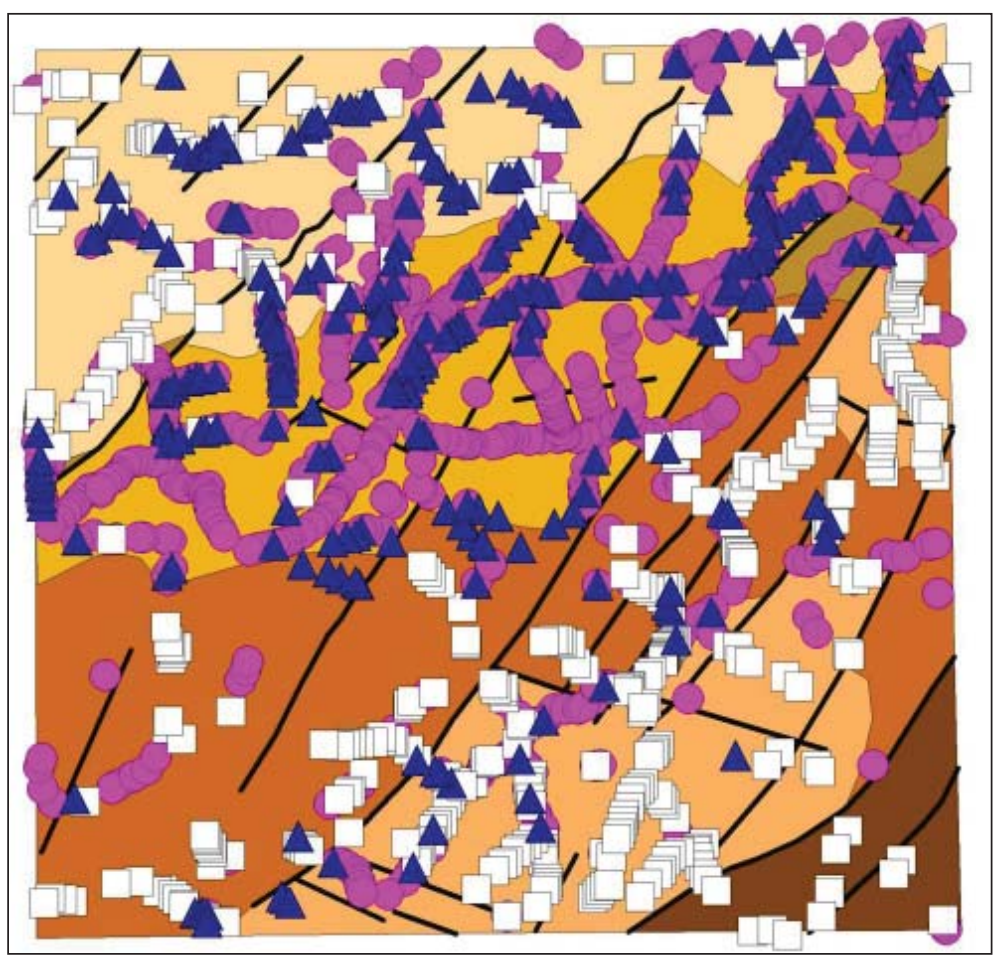

Figure 4. Data queried from the field database can be extremely useful in differentiating lithologies. In this Alaskan example, metamorphic units can largely be recognized by their relative abundance of garnet (pink circles), relict sandstone grains (white squares), and carbonate (blue triangles). Map area is about 14 by 14 miles. 
able for purchase the following year; however, testing multiple brands and generations of equipment and software is prohibitively expensive.

DGGS is currently field testing Samsung's Q1P SSD and Q1U-SSDXP tablet computers, the 12-channel DeLorme Earthmate BT-20 GPS, and the Kodak Easyshare V610 camera (discontinued product). (Note: Models listed are not necessarily all-inclusive of those potentially capable of meeting requirements for field entry of geologic data. Brand names are examples only and do not imply endorsement by the State of Alaska.) The full list of gear includes the computer, two 6-cell computer batteries, stylus, computer case, sealable plastic bags, screen protector, shoulder strap, GPS with extra battery, camera, mini tripod, and other camera accessories (fig. 5). The Q1P SSD units and all supporting equipment weigh $3.9 \mathrm{lbs}$. The Q1U-SSDXP units and all supporting equipment weigh $4.2 \mathrm{lbs}$.

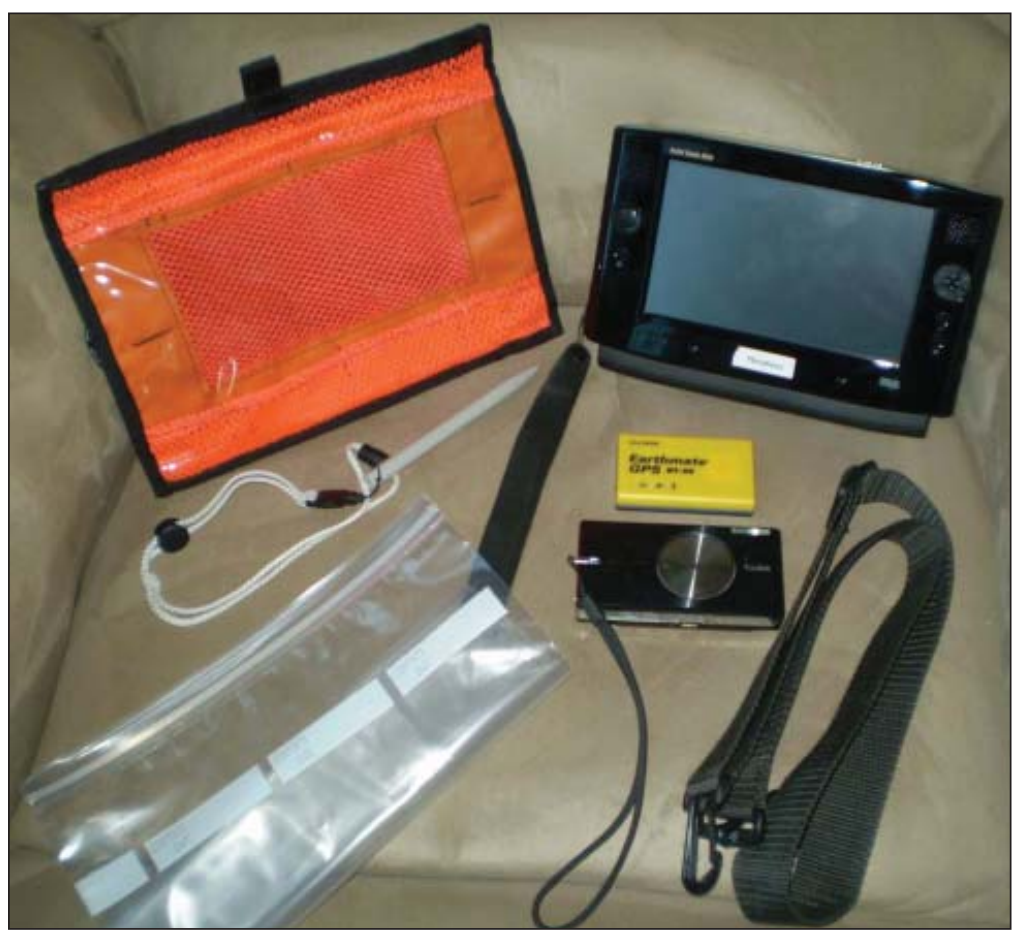

Figure 5. Q1P SSD tablet and supporting digital mapping equipment.

Table 1. DGGS's digital mapping requirements for hardware and software. Samsung's Q1 series does not have the features shown in italics. Some features may be added or configured with extra hardware or software.

\section{Essential features}

- Intuitive to learn and easy to use.

- Screen about 5" x 7"-compact but large enough to see map features.

- Lightweight - must be less than 3 lbs.

- Rugged, as typically defined by military standards and ingress protection ratings.

- Waterproof

- Transcription to digital text from handwriting and voice recognition.

- Can store paragraphs of data (text fields).

- Can store complex databases with dropdown lists.

- Screen is easy to read in bright sunlight and on gray sky days (could be configured).

- Removable static memory cards can be used to back up data.

- Chargeable by unconventional power sources (generators, solar, etc.).

- Wireless real-time link to GPS.

- Can change batteries in the field.

- Operating system and hardware are compatible with robust GIS program.

\section{Important features}

- USB port(s)

- Protective case (can be purchased separately for Q1U-SSDXP).

- At least 512 MB memory.

- Memory on board is recoverable.

- Batteries should have no "memory," such as with lithium ion.

- Wireless real-time link to computer, camera, and other peripherals.

- Portable battery with at least 9 hours of life at near constant use.

- Real-time and post-processing differential correction for GPS locations (could be configured). 
Software being tested includes ESRI's ArcPad 7.1.1, Geologic Data Assistant (GDA) extension for ArcPad (Thoms and Haugerud, 2006), Microsoft's Access and OneNote, and EverNote's RitePen. ArcPad and GDA are GIS software that work together with a GPS in real time to show the geologists' current location or to digitize new features on-screen. GDA, an ArcPad extension created for geologic mapping, has been upgraded from ArcPad 6.0.3 to version 7.1.1. DGGS is testing OneNote as a container for photographs, annotation, sketches, and narratives, and for its text recognition capability. Access houses the field database and is being tested as a field application. RitePen is a "write anywhere" handwriting recognition program that allows text entry in Access forms, as well as in many other programs.

\section{Digital Mapping Computer}

Two hardware requirements stood out as particularly important for the digital mapping computer - screen size and weight. Weight, in particular, is of tremendous concern. At the end of a field day, DGGS minerals geologists already regularly carry 80 $\mathrm{lb}$ of gear and rocks. From the computers and PDAs available in 2007, Samsung's Q1P SSD met the most requirements for our first attempt at digital mapping. Rejected options included PDAs because of their small screen size and lack of computing power, and rugged laptops and rugged tablets because of their heavier weight.
The Samsung Q1P SSD is a small but powerful tablet PC that runs Windows XP Tablet PC Edition. Its predecessor, Samsung's Q1, was one of the first Ultra-Mobile PCs (UMPC) launched in 2006 in response to Microsoft's Origami Project, a challenge to manufacturers to make a small, touch-screen computer, optimized for mobility. Since then, Samsung has offered several redesigned iterations of the computer, two of which are the Q1P SSD (discontinued product), and the Q1U-SSDXP (or Q1 Ultra SSDXP). DGGS is currently field testing two each of these computers. Both of the UMPCs feature a 32 GB solid state (NAND flash memory) hard drive. Hence, the computer does not have a spinning hard drive, is more resistant to damage from accidental drops than those with spinning hard drives, and creates less heat when operating. Additionally, battery life is significantly increased because a motor is not required to constantly spin the hard drive. Both computers also have a $7-$ inch screen and weigh less than $2 \mathrm{lbs}$ with the extended 6-cell battery. See table 2 for their specifications.

For use as a DGGS field computer, the biggest drawbacks of the Q1 series are their limited ruggedness and lack of waterproofing. Custom carrying cases were locally manufactured by Apocalypse Design, Inc. for the Q1P SSD tablets that add protection from drops and contact with rocks. The case has a plastic shield to protect the tablet's writing surface, mesh fabric that allows air circulation, and several tabs to attach carrying straps. The Q1U-SSDXP tablets have carrying cases manufac-

Table 2. Selected specifications for the Q1P SSD and Q1U-SSDXP from http://www.samsung.com/.

\begin{tabular}{|c|c|c|}
\hline Feature & Q1P SSD & Q1U-SSDXP \\
\hline Operating system & Windows XP Tablet Edition & Windows XP Tablet Edition \\
\hline Processor & $\begin{array}{l}\text { Intel Pentium M ULV, } \\
1.0 \mathrm{GHz}\end{array}$ & $\begin{array}{l}\text { Intel Ultra Mobile Processor } \\
\text { A110, } 800 \mathrm{MHz}\end{array}$ \\
\hline Storage & 32GB SSD & 32GB SSD \\
\hline Memory & 1GB DDRII 533 & 1 GB DDRII 400 \\
\hline Graphics & $\begin{array}{l}\text { Intel } \AA \text { Graphics Media } \\
\text { Accelerator } 900,128 \mathrm{MB}\end{array}$ & $\begin{array}{l}\text { Intel }{ }^{\circledR} \text { Graphics Media } \\
\text { Accelerator } 950,128 \mathrm{MB}\end{array}$ \\
\hline Display & $\begin{array}{l}\text { 7" WVGA Touch Screen LCD, } \\
800 \times 480,280 \text { nits }\end{array}$ & $\begin{array}{l}\text { 7" WSVGA Touch Screen LCD, } \\
1024 \text { x 600, } 300 \text { nits }\end{array}$ \\
\hline Communications & $\begin{array}{l}802.11 \mathrm{~b} / \mathrm{g} \text { Wi-Fi, } \\
\text { 10/100 Base-TX Ethernet, } \\
\text { Bluetooth } 2.0\end{array}$ & $\begin{array}{l}802.11 \mathrm{~b} / \mathrm{g} \mathrm{Wi}-\mathrm{Fi} \text {, } \\
\text { 10/100 Base-TX Ethernet, } \\
\text { Bluetooth } 2.0+\text { EDR }\end{array}$ \\
\hline Ports & $\begin{array}{l}\text { Two USB } 2.0 \text {, } \\
\text { One Type II CF card, } \\
\text { Headphone Jack, } \\
\text { VGA }\end{array}$ & $\begin{array}{l}\text { Two USB 2.0, } \\
\text { 2-in-1 Memory Slot (SD/MMC), } \\
\text { Headphone Jack, } \\
\text { VGA }\end{array}$ \\
\hline Dimension & $9.0 \times 5.5 \times 1.0$ inches & $8.96 \times 4.88 \times 0.93$ inches \\
\hline Weight with battery & $1.7 \mathrm{lbs}$ (with 3-cell battery) & $1.4 \mathrm{lbs}$ (with 4-cell battery) \\
\hline Keyboard & N/A & QWERTY Key Pad \\
\hline Camera(s) & N/A & $\begin{array}{l}\text { Front Facing Video } 300 \text { P, } \\
\text { Rear Facing Video/Still 1.3 MP }\end{array}$ \\
\hline
\end{tabular}


tured by OtterBox. The OtterBox 1990 Defender Case for Q1 Ultra UMPCs has a thermal-formed protective clear membrane to protect the writing surface, a high-impact polycarbonate shell, and a silicone layer that covers the unit and its ports. Both cases provide some water resistance but do not make the tablets waterproof.

Although inherently problematic, sealable plastic bags were determined to be the tablets' best protection against water intrusion. Concern about overheating problems due to lack of air flow in the plastic bags led to a series of heat tests. A Q1P SSD tablet was set up with a program that measures ambient air temperature, graphics processing unit (GPU) temperature, memory temperature, and CPU die-core temperature. To ensure that the computer generated the most heat possible, a process was activated that writes to and then erases 80 percent of the available memory while drawing random polygons on the screen, and that uses leftover CPU cycles to compute the square root of a random 25 digit number.

The computer was placed in a sealed plastic bag, and its temperatures were monitored over the life of the standard 3-cell battery while the computer was located at room temperature and then in a $150^{\circ} \mathrm{F}$ oven. Then the computer was turned off, placed in its sealed bag, and chilled overnight in a $-25^{\circ} \mathrm{F}$ freezer. In the morning, the heat-generating processes were restarted. The computer was placed back in a sealed plastic bag and again in the oven at $150^{\circ} \mathrm{F}$ until the battery ran down. While the CPU did in fact slow down during these tests, it never faltered, never shut down, and never melted. The computer's self-preservation mechanism (based on temperature) slowed the processor down to slower and slower speeds in order to consume less power, thereby creating less heat.

\section{Field TeST}

During the summer 2007 field season, two geologists using Q1P SSD tablets tested the digital mapping equipment for one day. Hardware and setup issues included poor screen visibility in bright sunlight (fig. 6) and Bluetooth connection problems with the camera. It was feasible but inconvenient to cover the computer with two layers of plastic (case and sealed plastic bag) while trying to operate the buttons, and the plastic layers made screen-viewing more difficult.

In a similar field situation with Samsung Q1P series computers, Alaska Division of Forestry (DOF) field personnel had difficulty maintaining consistent Bluetooth GPS connections. DOF prefers built-in GPSs. Their temporary solution is to use external plug-in CF GPS receivers; however, field personnel have broken off two external antennas during normal use. DOF solved the screen visibility problem by replacing their computers' screens (3 Q1P and 2 rugged laptops) with Advanced Link Photonics, Inc. resistive touch transflective LCD screens (Thomas Kurkowski, oral commun., 2008). The enhanced resistive touch screens reduce glare from 10 to 20 percent on regular screens to 1 percent reflected light, and the LCD screens are transflectively upgraded and often brighter with an increase in nits by $10-30$ percent (Advanced Link Photonics, Inc., oral commun., 2008).
Software issues included frequent virus software popup messages, problems recording lengthy text and with text recognition in Microsoft OneNote, and GDA incompatibility with DGGS-style field notes. In general, more time needs to be spent setting up an easy-on, automatically configured interface for field geologists so there are no or minimal technical details to manage in the field. To truly have a seamless field data entry system requires a customized, form-based, GIS-database interface.

\section{Field Test}

Several personnel from DGGS Mineral Resources and Engineering Geology sections are currently testing the Q1P SSD and Q1U-SSDXP field computers. In 2008, the Access field database was replicated and placed on the tablets for direct data entry. RitePen text recognition software was provided for data entry into the Access form. Staff set up ArcPad with project GIS files to automatically load with the program, and configured GPSs with Bluetooth to provide location information to ArcPad and GDA. A Bluetooth camera was also configured to add pictures to Microsoft OneNote, where they will be annotated.

Initial impressions are that the digital mapping hardware and software were better configured this year than in 2007, but that the geologists were not adequately prepared to use the equipment. Most geologists were not familiar enough with the tablet computers, Access database, new GPSs, and how the text recognition software worked to complete meaningful field data entry. Geologists were also fearful that they would damage the hardware and were reluctant to carry it, especially in inclement

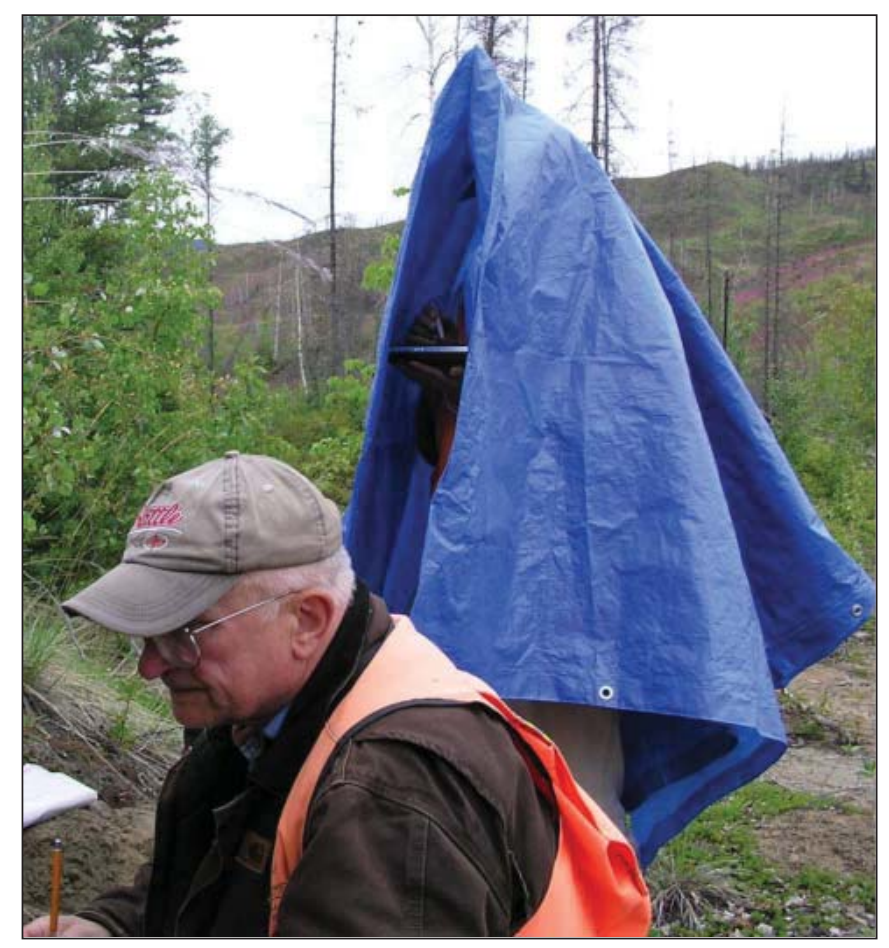

Figure 6. Surficial geologists Dick Reger (bottom left) and Trent Hubbard (under tarp) attempt to minimize screen glare and protect unit from rain while working. 


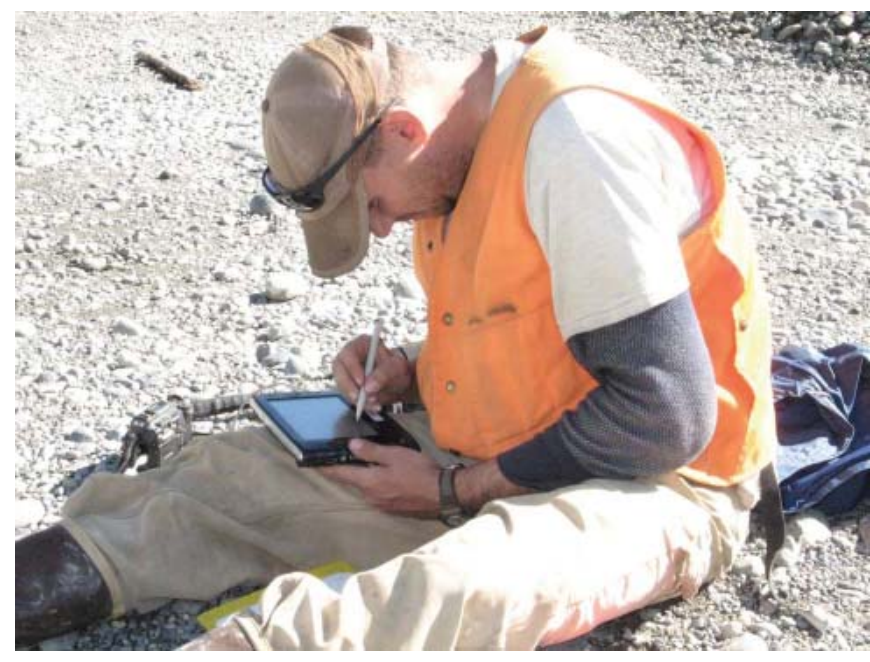

Figure 7. Geologist Trent Hubbard successfully records geologic data digitally.

weather. Thus far, positive feedback includes good performance by the RitePen text recognition software, seamless GPS connectivity via Bluetooth, good performance by the system overall as a navigational aid in the helicopter, successful capture of geologic contacts and attribute data (fig. 7), and potential use of the computer as a pocket handwarmer.

\section{FUTURE OF DIGITAL MAPPING AT DGGS}

Before the next field season, interested DGGS geologists will spend more time learning to use the computers and software so that they are comfortable enough with them to collect at least several days' worth of data in the field. For 2009, there will probably only be minor changes to the configuration of the computers. New daylight readable screens may be the biggest potential improvement in the system.

In the long term, some significant software changes are necessary to truly make digital mapping viable. The biggest hurdle will be creating a simple, user-friendly, form-based interface in ArcPad that can capture GIS features as well as detailed geologic data at field stations. Before that can happen, however, we must migrate the Access database to ESRI ArcMap, and then serve the data out to ArcPad.

In conjunction with the move, the field database will probably be redesigned to more closely match the structure of DGGS's enterprise Oracle database (Freeman and others, 2002; Freeman and Sturmann, 2004). The redesign, development of data loading routines, and decisions about data flow and editing could start in mid 2009. To date, only basic station and sample field data from recent projects have been entered into the enterprise database. DGGS has had little time and no dedicated funding to perform this task. With the field database redesign, we hope that after the data have been quality controlled, it will be a fairly simple matter to load all of the data into the Oracle database.

The next step, creation of the data entry form using ESRI's ArcPad and ArcPad Application Builder, could begin in 2010. Design of the form will also require Visual Basic Scripting, possibly developed with the help of an outside contract. The interface will be designed for geologists' ease of use and could be field tested as early as 2011 .

\section{CONCLUSIONS}

DGGS recognizes that the current methodology of geologic mapping can be more efficient, especially in the way field data are recorded. DGGS minerals geologists currently write field station and sample observations on note cards, which are later entered into an Access database by a student intern. In the past, data entry by student interns has taken up to seven months. Given the limited amount of time available to complete mapping projects, this excessive period of data entry is unacceptable.

DGGS is considering digital mapping as a way to streamline the mapping process. To that end, we are evaluating the effectiveness of entering field-geologic observations directly into an Access database and GIS software on Samsung ultramobile tablet computers. Brief field tests in 2007 and 2008 suggest that the equipment and software have the potential to work as a digital mapping system, but that significant work is still needed to create a system that will facilitate comfortable data entry by field geologists.

We will continue to work on new solutions and keep an eye out for new technology that will help alleviate some of the problems discovered thus far, including limited ruggedness and lack of waterproofing of the units. In the next couple of years, DGGS will train additional geologists on the computers and software so that we can then conduct more comprehensive field tests. Future plans include migration of the field database to ESRI's ArcMap and ArcPad, and creating a user friendly GIS-database data-entry interface. Through sharing ideas and results, we anticipate that it will be possible to create a DGGSwide digital mapping system capable of benefiting all of the field projects. If the process proves effective, we anticipate that within a few years most DGGS geologists will be out on the outcrop with little field computers, happily, but more efficiently, creating geologic maps, reports, and digital data to better serve the public's needs for resource evaluation, hazards identification, and well informed land-use management.

\section{REFERENCES}

Freeman, Larry, Engle, Kathryn, and Browne, Carrie, 2002, Alaska Division of Geological \& Geophysical Surveys geologic database development—Logical model, in Soller, D.R., ed., Digital Mapping Techniques '02-Workshop Proceedings: U.S. Geological Survey Open-File Report 02-370, p. 157-160, accessed at http://pubs.usgs. gov/of/2002/of02-370/freeman.html.

Freeman, Larry, and Sturmann, Fred, 2004, Progress towards an agency-wide geologic map database at Alaska Division of Geological \& Geophysical Surveys, in Soller, D.R., ed., Digital Mapping Techniques '04 - Workshop Proceedings: U.S. Geological Survey Open-File Report 04-1451, p. 9-14, accessed at http://pubs.usgs. gov/of/2004/1451/freeman/index.html.

Thoms, E.E., and Haugerud, R.A, 2006, GDA (Geologic Data Assistant), an ArcPad extension for geologic mapping: Code, prerequisites, and instructions: U.S. Geological Survey OpenFile Report 2006-1097, 23 p., accessed at http://pubs.usgs.gov/ of $/ 2006 / 1097 /$. 


\section{Dear Readers:}

Fall is a time for reflection, which can be both satisfying and unsettling. When I look around home at the many half-finished projects that will soon be covered by snow; it is an unsettling moment. When I look at what the staff at DGGS has accomplished this past summer, even with all the marginal weather we experienced this year, I am overly satisfied and proud. This short column is not the place to go through all the DGGS activities, and I encourage you to visit our website at http://www.dggs. dnr.state.ak.us/ and download our 2008 Annual Report when it is posted in January, but I would like to at least give you a sneak preview.

The pipeline corridor project completed the next-to-last phase of geologic mapping and neotectonic analysis between Delta and Tok. The energy group finalized the Bristol Bay program, finished mapping in the Sagavanirktok area, and completed two short field programs in the Cook Inlet region. The minerals group dodged clouds and snowstorms and mapped some exciting geology in the north-central Alaska Range where they are making great strides in deciphering the bedrock geology and structure in the eastern Bonnifield area and along the proposed pipeline corridor. The engineering geology group took the lead on surficial mapping in nearly all the field areas and spearheaded an impressive array of field trip guidebooks associated with the Ninth International Conference on Permafrost. The publications section kept all the data flowing through to our customers. The volcanology group has been especially busy with fieldwork and unprecedented eruptive activity out on the Aleutian Chain. Yes, a lot has been accomplished here at DGGS since my last writing.

We also have a number of personnel transitions of note. We have hired a new Quaternary mapper in the engineering geology group, Trent Hubbard, and a new geologist in our minerals section, Joe Andrew. Joe's expertise is in structural geology and tectonics in metamorphic and igneous terrains. Jean Riordan has rejoined the Geologic Materials Center in Eagle River and is helping us get a searchable database for our collection on the web. We are very excited to have these new geologists join us. We also have a number of great student interns without whom we would not be able to get it all done. Geologists Paige Delaney, Ken Papp, Susan Brown, and Sharon Hansen all moved on to new horizons and we wish them great success in their new roles.

I won't say much about the challenging times that we are all living through given the big changes in energy and economic stability of the U.S. Clearly, we will all be faced with some very important decisions concerning the short- and long-term stability of our state and the nation. What I will say is that DNR, and DGGS, are engaged at all levels trying to address the difficult issues in energy and resource development, and public safety from geologic hazards across the state, for the benefit of all citizens.

Please stop by our offices if you would like to discuss, or get information on, any of the current or potential DGGS activities,

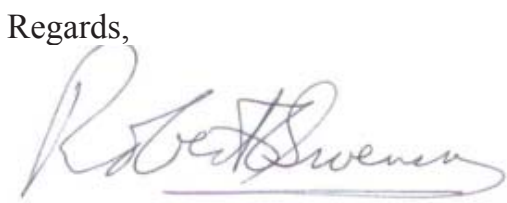

Bob Swenson

State Geologist \& Director

\section{NEW DGGS PUBLICATIONS}

\section{GEOPHYSICAL MAPS \& REPORTS}

GPR 2006-8. Final processed database for the airborne geophysical surveys of the Alaska Highway corridor, east-central Alaska, by Burns, L.E., Fugro Airborne Surveys Corp., and Stevens Exploration Management Corp., 2008, 1 disk. 1 DVD \$15.

GPR 2008-3. Line, grid, and vector data, and plot files for the airborne geophysical survey of the Styx River Survey, southcentral Alaska, by Burns, L.E., Fugro Airborne Surveys Corp., and Stevens Exploration Management Corp., 2008, 27 sheets, 1 disk. 1 DVD. Supersedes GPR 2008-2. Download the digital data free of charge. $\$ 15$.

GPR 2008-3-1A. Total magnetic field of the western Styx River Survey, southcentral Alaska, by Burns, L.E., Fugro Airborne Surveys Corp., and Stevens Exploration Management Corp., 2008, 1 sheet, scale 1:63,360. Topography included. $\$ 13$.

GPR 2008-3-1B. Total magnetic field of the southern Styx River Survey, southcentral Alaska, by Burns, L.E., Fugro Airborne Surveys
Corp., and Stevens Exploration Management Corp., 2008, 1 sheet, scale 1:63,360. Topography included. \$13.

GPR 2008-3-1C. Total magnetic field of the eastern Styx River Survey, southcentral Alaska, by Burns, L.E., Fugro Airborne Surveys Corp., and Stevens Exploration Management Corp., 2008, 1 sheet, scale 1:63,360. Topography included. $\$ 13$.

GPR 2008-3-2A. Total magnetic field of the western Styx River Survey, southcentral Alaska, by Burns, L.E., 2008, 1 sheet, scale 1:63,360. Magnetic contours included. \$13.

GPR 2008-3-2B. Total magnetic field of the southern Styx River Survey, southcentral Alaska, by Burns, L.E., Fugro Airborne Surveys Corp., and Stevens Exploration Management Corp., 2008, 1 sheet, scale 1:63,360. Magnetic countours included. \$13.

GPR 2008-3-2C. Total magnetic field of the eastern Styx River Survey, southcentral Alaska, by Burns, L.E., Fugro Airborne Surveys Corp., and Stevens Exploration Management Corp., 2008, 1 sheet, scale 1:63,360. Magnetic contours included. \$13. 
GPR 2008-3-3A. First vertical derivative of the total magnetic field of the western Styx River Survey, southcentral Alaska, by Burns, L.E., 2008, 1 sheet, scale 1:63,360. Topography included. \$13.

GPR 2008-3-3B. First vertical derivative of the total magnetic field of the southern Styx River Survey, southcentral Alaska, by Burns, L.E., Fugro Airborne Surveys Corp., and Stevens Exploration Management Corp., 2008, 1 sheet, scale 1:63,360. Topography included. \$13.

GPR 2008-3-3C. First vertical derivative of the total magnetic field of the eastern Styx River Survey, southcentral Alaska, by Burns, L.E., Fugro Airborne Surveys Corp., and Stevens Exploration Management Corp., 2008, 1 sheet, scale 1:63,360. Topography included. $\$ 13$.

GPR 2008-3-4A. 56,000 Hz coplanar apparent resistivity of the western Styx River Survey, southcentral Alaska, by Burns, L.E., Fugro Airborne Surveys Corp., and Stevens Exploration Management Corp., 2008, 1 sheet, scale 1:63,360. Topography included. \$13.

GPR 2008-3-4B. 56,000 Hz coplanar apparent resistivity of the southern Styx River Survey, southcentral Alaska, by Burns, L.E., Fugro Airborne Surveys Corp., and Stevens Exploration Inc., 2008, 1 sheet, scale 1:63,360. Topography included. \$13.

GPR 2008-3-4C. 56,000 Hz coplanar apparent resistivity of theeastern Styx River Survey, southcentral Alaska, by Burns, L.E., Fugro Airborne Surveys Corp., and Stevens Exploration Management Corp., 2008, 1 sheet, scale 1:63,360. Topography included. \$13.

GPR 2008-3-5A. 56,000 Hz coplanar apparent resistivity of the western Styx River Survey, southcentral Alaska, by Burns, L.E., Fugro Airborne Surveys Corp., and Stevens Exploration Management Corp., 2008, 1 sheet, scale 1:63,360. Resistivity contours included. \$13.

GPR 2008-3-5B. 56,000 Hz coplanar apparent resistivity of the southern Styx River Survey, southcentral Alaska, by Burns, L.E., Fugro Airborne Surveys Corp., and Stevens Exploration Management Corp., 2008, 1 sheet, scale 1:63,360. Resistivity contours included. $\$ 13$.

GPR 2008-3-5C. 56,000 Hz coplanar apparent resistivity of the eastern Styx River Survey, southcentral Alaska, by Burns, L.E., Fugro Airborne Surveys Corp., and Stevens Exploration Management Corp., 2008, 1 sheet, scale 1:63,360. Resistivity contours included. \$13.

GPR 2008-3-6A. $7200 \mathrm{~Hz}$ coplanar apparent resistivity of the western Styx River Survey, southcentral Alaska, by Burns, L.E., Fugro Airborne Surveys Corp., and Stevens Exploration Management Corp., 2008, 1 sheet, scale 1:63,360. Topography included. \$13.

GPR 2008-3-6B. $7200 \mathrm{~Hz}$ coplanar apparent resistivity of the southern Styx River Survey, southcentral Alaska, by Burns, L.E., Fugro Airborne Surveys Corp., and Stevens Exploration Management Corp., 2008, 1 sheet, scale 1:63,360. Topography included. \$13.

GPR 2008-3-6C. $7200 \mathrm{~Hz}$ coplanar apparent resistivity of the eastern Styx River Survey, southcentral Alaska, by Burns, L.E., Fugro Airborne Surveys Corp., and Stevens Exploration Management Corp., 2008, 1 sheet, scale 1:63,360. Topography included. \$13.

GPR 2008-3-7A. $7200 \mathrm{~Hz}$ coplanar apparent resistivity of the western Styx River Survey, southcentral Alaska, by Burns, L.E., Fugro Airborne Surveys Corp., and Stevens Exploration Management Corp., 2008, 1 sheet, scale 1:63,360. Resistivity contours included. $\$ 13$.

GPR 2008-3-7B. $7200 \mathrm{~Hz}$ coplanar apparent resistivity of the southern Styx River Survey, southcentral Alaska, by Burns, L.E., Fugro Airborne Surveys Corp., and Stevens Exploration Management Corp., 2008, 1 sheet, scale 1:63,360. Resistivity contours included. \$13.
GPR 2008-3-7C. $7200 \mathrm{~Hz}$ coplanar apparent resistivity of the eastern Styx River Survey, southcentral Alaska, by Burns, L.E., Fugro Airborne Surveys Corp., and Stevens Exploration Management Corp., 2008, 1 sheet, scale 1:63,360. Resistivity contours included. $\$ 13$.

GPR 2008-3-8A. $900 \mathrm{~Hz}$ coplanar apparent resistivity of the western Styx River Survey, southcentral Alaska, by Burns, L.E., Fugro Airborne Surveys Corp., and Stevens Exploration Management Corp., 2008, 1 sheet, scale 1:63,360. Topography included. \$13.

GPR 2008-3-8B. $900 \mathrm{~Hz}$ coplanar apparent resistivity of the southern Styx River Survey, southcentral Alaska, by Burns, L.E., Fugro Airborne Surveys Corp., and Stevens Exploration Management Corp., 2008, 1 sheet, scale 1:63,360. Topography included. \$13.

GPR 2008-3-8C. $900 \mathrm{~Hz}$ coplanar apparent resistivity of the eastern Styx River Survey, southcentral Alaska, by Burns, L.E., Fugro Airborne Surveys Corp., and Stevens Exploration Ma.nagement Corp., 2008, 1 sheet, scale 1:63,360. Topography included. \$13.

GPR 2008-3-9A. $900 \mathrm{~Hz}$ coplanar apparent resistivity of the western Styx River Survey, southcentral Alaska, by Burns, L.E., Fugro Airborne Surveys Corp., and Stevens Exploration Management Corp., 2008, 1 sheet, scale 1:63,360. Resistivity contours included. \$13.

GPR 2008-3-9B. $900 \mathrm{~Hz}$ coplanar apparent resistivity of the southern Styx River Survey, southcentral Alaska, by Burns, L.E., Fugro Airborne Surveys Corp., and Stevens Exploration Management Corp., 2008, 1 sheet, scale 1:63,360. Resistivity contours included. \$13.

GPR 2008-3-9C. $900 \mathrm{~Hz}$ coplanar apparent resistivity of the eastern Styx River Survey, southcentral Alaska, by Burns, L.E., and Fugro Airborne Surveys Corp., 2008, 1 sheet, scale 1:63,360. Resistivity contours included. $\$ 13$.

GPR 2008-4. Linedata and gridded data for the aeromagnetic survey of the Holitna basin area, western Alaska: Parts of the Lime Hills and Sleetmute quadrangles, by Burns, L.E., SIAL Geosciences Inc., and On-line Exploration Services Inc., 2008, 1 sheet, 1 disk. 1 CD-ROM. http://www.dggs.dnr.state.ak.us/GPR2008-4/ Download the digital data free of charge. $\$ 10$.

\section{NEWSLETTER}

NL 2008-1. Alaska GeoSurvey News, by DGGS Staff, 2008, 14 p. Free.

\section{PRELIMINARY INTERPRETIVE REPORT}

PIR 2008-1. Preliminary results of recent geologic field investigations in the Brooks Range Foothills and North Slope, Alaska, by Wartes, M.A., and Decker, P.L., 2008, 206 p. \$112.

PIR 2008-1A. Overview of recent geologic field investigations, North Slope and Brooks Range foothills, Alaska, by Wartes, M.A., and Decker, P.L., 2008, 1 sheet.

PIR 2008-1B. Measured section and facies analysis of the Lower Cretaceous Fortress Mountain Formation, Atigun syncline, northern Alaska, by Wartes, M.A., 2008, 1 sheet.

PIR 2008-1C. Evaluation of stratigraphic continuity between the Fortress Mountain and Nanushuk Formations in the central Brooks Range foothills-Are they partly correlative?, by Wartes, M.A., 2008.

PIR 2008-1D. Measured sections and preliminary interpretations of the Nanushuk Formation exposed along the 
Colville River near the confluences with the Awuna and Killik rivers, by LePain, D.L., Decker, P.L., and Wartes, M.A., 2008, 4 sheets.

PIR 2008-1E. Geochemistry of the Aupuk gas seep along the Colville River-Evidence for a thermogenic origin, by Decker, P.L., and Wartes, M.A., 2008.

PIR 2008-1F. Stratigraphic and structural investigations in the Ivishak River and Gilead Creek areas: Progress during 2007, by Decker, P.L., Wartes, M.A., Wallace, W.K., Houseknecht, D.W., Schenk, C.J., Gillis, R.J., and Mongrain, J., 2008, 1 sheet.

PIR 2008-1G. Turonian-Campanian strata east of the TransAlaska Pipeline corridor, North Slope foothills, Alaska: Progress during the 2001-02 and 2007 field seasons, by LePain, D.L., Kirkham, Russell, Gillis, R.J., and Mongrain, J., 2008.

PIR 2008-2. Jurassic through Pliocene age megafossil samples collected in 2005 by the Alaska Divison of Geological \& Geophysical Surveys from the Bristol Bay-Port Moller area, Alaska Peninsula, by Blodgett, R.B., Finzel, E.S., Reifenstuhl, R.R., Clautice, K.H., Ridgway, K.D., and Gillis, R.J., 2008, 12 p. \$2.
PIR 2008-3C. Reconnaissance interpretation of permafrost, Alaska Highway corridor, Delta Junction to Dot Lake, Alaska, by Reger, R.D., and Solie, D.N., 2008, 10 p., 2 sheets, scale 1:63,360. $\$ 28$.

\section{RAW DATA FILES}

RDF 2008-3. Preliminary bathymetric map of Mother Goose Lake, Alaska Peninsula, by Schaefer, J.R., Wallace, K.L., and Kassel, C.M., 2008. Free.

RDF 2008-4. 40Ar/39Ar ages from the Tyonek D-6 Quadrangle and parts of the Tyonek D-7, Tyonek D-5 and Tyonek C-6 quadrangles, Alaska, by Layer, P.W., and Solie, D.N., 2008, 14 p. \$2.

\section{REPORT OF INVESTIGATIONS}

Reger, R.D., Burns, P.A.C., and Staft L.A., 2008, Surficial-geologic map of the Salcha River - Pogo area, eastcentral Alaska: Alaska Division of Geological \& Geophysical Surveys Report of Investigations 2004-1C, 1 sheet, scale 1:63,360.

\section{SPECIAL REPORTS}

SR 62. Alaska's Mineral Industry 2007, by Szumigala, D.J., Hughes, R.A., and Harbo, L.A., 2008, 89 p. Free.

\section{ORDERING INFORMATION}

For each publication ordered, include both the publication title and number. Mail orders are payable in advance. Make check or money order in U.S. currency and payable to the State of Alaska. Credit cards are accepted. Telephone orders are accepted by the Fairbanks office between 8 a.m. and 4:30 p.m. Alaska time. Fax and email requests are accepted any time; these orders will be invoiced. If you would like to leave your order on voice mail, this can also be done 24 hours a day and you will be invoiced.

\section{SHIPPING \& HANDLING}

Shipping charge will be the actual cost of postage and will be added to the total amount due. Please e-mail or call for an exact amount.

\section{WHERE TO ORDER}

Publications of the Division of Geological \& Geophysical Surveys are available over the counter, by mail, phone, fax, or email from the DGGS Fairbanks office:

ATTN: Geologic Communications Section-Publication Sales Alaska Division of Geological \& Geophysical Surveys, 3354 College Rd. Fairbanks, AK 99709-3707

(907) 451-5020 Fax (907) 451-5050

Email: dggspubs@alaska.gov

Prices of DGGS publications are subject to change. Increases in costs make it necessary to raise the selling prices of many publications offered. It is not feasible for DGGS to change the prices stated in previous announcements and publications in stock, so the prices charged may differ from the prices in the announcements and publications. Overpayments of $\$ 2$ or less will not be refunded.

\begin{tabular}{|c|}
\hline Please send address corrections to: \\
Newsletter, Alaska Division of Geological \& Geophysical Surveys \\
3354 College Rd., Fairbanks, AK 99709-3707 \\
(907) 451-5020 (907)451-5050 fax \\
email: dggsnews@dnr.state.ak.us \\
http://www.dggs.dnr.state.ak.us \\
\hline
\end{tabular}




\section{STATE OF ALASKA \\ DEPARTMENT OF NATURAL RESOURCES \\ DIVISION OF GEOLOGICAL \& GEOPHYSICAL SURVEYS}

Mail order to:

Alaska Division of Geological \& Geophysical Surveys

Attn: Geologic Communications Section

3354 College Rd.

Fairbanks, Alaska 99709-3707
E-mail: dggspubs@alaska.gov

http://www.dggs.dnr.state.ak.us

(907) 451-5020

Fax: (907) 451-5050

\begin{tabular}{|c|c|c|c|}
\hline Report Number & Report Name & Quantity & Price \\
\hline & & & \\
\hline & & & \\
\hline & & & \\
\hline & & & \\
\hline & & & \\
\hline & & & \\
\hline & & & \\
\hline & & & \\
\hline & & & \\
\hline & & & \\
\hline & & & \\
\hline & $\begin{array}{r}\text { Total Publications } \\
\text { Shipping and Handling Charge }\end{array}$ & & \\
\hline & Total for all Publications and Shipping & & \\
\hline & Amount Paid & & \\
\hline & AMOUNT DUE & & \\
\hline
\end{tabular}

POSTAGE: Shipping charge will be the actual cost of postage and will be added to the total amount due. You may e-mail or call for an exact amount.

\section{Ship publication(s) to:}

Name

Organization

Address

City, State

Zip

Payment must accompany your order. Make check or money order payable to STATE OF ALASKA. We accept Visa and MasterCard. For payment by credit card, please contact our office at (907) 451-5020. 